\title{
POTENSI SENYAWA FLAVONOID DAUN AFRIKA (Vernonia amygdalina Del.) ASAL TERNATE SEBAGAI ANTIOKSIDAN
}

\author{
Sukmawati, Harira Hadi, Aminah \\ Fakultas Farmasi Universitas Muslim Indonesia, Makassar \\ Email: sukmawati.syarif@umi.ac.id
}

\begin{abstract}
African Leaf (Vernonia amygdalina Del.) belonging Asteraceae family. The African leaf contain flavonoids, alkaloids, saponins, terpenoids, tannins, glycosides, indole alkaloids, anthraquinones and luteolin. This study aimed to measure the potencyl of flavonoid compounds of African leaf (Vernonia amygdalina Del.) origin Ternate using DPPH and FRAP. Extraction by maceration method using ethanol 96\%. The compounds identification in African leaf extract contains flavonoids. The absorbance was measured at the maximum wavelength of $515 \mathrm{~nm}$. DPPH scavenging showed that ethanol extract has weak antioxidant activity based on AAI 0.454 value. This potency is lower in comparasion with quersetin which has a value of AAl 6,315 and for FRAP methods, the absorbance was measured at the wavelength of $720 \mathrm{~nm}$ with the antioxidant capacity is 14,846 mgQE / gram.
\end{abstract}

Key words : Antioxidant, African Leaves, DPPH, FRAP.

\section{PENDAHULUAN}

Tumbuhan Afrika (Vernonia amygdalina Del.) memiliki sinonim Gymnanthemum amygdalinum di Indonesia dikenal dengan nama daun Afrika. Tanaman daun Afrika banyak mengandung nutrisi dan senyawa kimia, antara lain protein $19,2 \%$, serat $19,2 \%$, karbohidrat $68,4 \%$, lemak $4,7 \%$, asam askorbat $166,5 \mathrm{mg} / 100 \mathrm{~g}$, karotenoid $30 \mathrm{mg} / 100 \mathrm{~g}$, kalsium $0,97 \mathrm{~g} / 100 \mathrm{~g}$, besi $7,5 \mathrm{mg} / 100 \mathrm{gram}^{3}$ Sedangkan senyawa kimia yang terkandung dalam daun Afrika antara lain flavonoid, alkaloid, saponin, terpenoid, tanin, glikosida, alkaloid indole, antrakuinon dan luteolin. ${ }^{1}$

Penggunaan daun afrika secara empiris oleh masyarakat digunakan untuk berbagai penyakit diantaranya sebagai obat antikanker, mencegah penyakit jantung, penurunkan kolesterol, mencegah stroke, menurunkan gula darah, gangguan pencernaan dan penurun berat badan. $^{2}$

Salah satu penelitian melaporkan bahwa ekstrak etanol daun afrika dapat menurukan kadar 
Potensi senyawa flavonoid daun afrika (Vernonia amygdalina Del.) asal Ternate sebagai antioksidan

glukosa darah dan memiliki efektivitas sebagai antibakteri. $^{3}$

Senyawa flavonoid juga terbukti mempunyai efek biologis yang sangat kuat, yaitu sebagai antioksidan. 4

Oleh karena itu, berdasarkan uraian di atas maka penelitian ini dilakukan untuk mengetahui potensi senyawa flavonoid pada daun Afrika (Vernonia amygdalina Del.) Asal Ternate sebagai antioksidan.

\section{METODE PENELITIAN}

\section{Pengambilan dan Pengolahan}

Sampel

Sampel daun Afrika (Vernonia amygdalina Del.) diambil di kota Ternate, provinsi Maluku Utara. Sampel kemudian dibersihkan dari kotoran yang melekat dengan menggunakan air mengalir lalu dikeringkan dengan cara dianginanginkan. Setelah kering, sampel dipotong-potong dan diserbukkan.

\section{Ekstraksi sampel}

Sampel kering yang telah di haluskan diambil dan dimasukkan kedalam wadah untuk dimaserasi, kemudian ditambahkan etanol 96\% sebanyak $500 \mathrm{~mL}$ hingga simplisia tersebut terendam, dibiarkan selama 1x24 jam dalam bejana tertutup, setelah itu simplisia disaring. Maserasi dilanjutkan kembali selama 1x24 jam dengan pelarut etanol $96 \%$ yang baru sebanyak $500 \mathrm{~mL}$, kemudian disaring kembali. Ekstrak etanol yang telah diperoleh dikumpulkan kemudian diuapkan dengan rotavapor dan didapatkan ekstrak kental ${ }^{[5]}$

\section{Identifikasi Senyawa Flavonoid}

Larutan ekstrak sebanyak $2 \mathrm{~mL}$ ditambah dengan sedikit serbuk magnesium dan $2 \mathrm{~mL} \mathrm{HCl} 2 \mathrm{~N}$. Senyawa flavonoid akan menimbulkan warna jingga sampai merah ${ }^{[6]}$

\section{Pengukuran Panjang Gelombang Maksimum Larutan DPPH}

Larutan DPPH dengan konsentrasi 40 ppm dipipet $4 \mathrm{~mL}$ kemudian larutan diinkubasi selama 30 menit dan diukur absorbansinya pada panjang gelombang 490--535 nm.

\section{Pengukuran Aktivitas Antioksidan Pembanding Kuersetin}

Larutan stok 1000 ppm dibuat dengan cara menimbang $10 \mathrm{mg}$ kuersetin, kemudian dilarutkan dengan metanol p.a sambil diaduk dan dihomogenkan lalu dicukupkan volumenya hingga $10 \mathrm{~mL}$. Selanjutnya dilakukan pengenceran dengan seri konsentrasi 2 ppm, 4 ppm, 6 ppm, 8 ppm,10 ppm, kemudian dicukupkan volumenya hingga $5 \mathrm{~mL}$.

Pengujian dilakukan cara dipipet 0,5 $\mathrm{mL}$ larutan sampel dari berbagai konsentrasi. Kemudian masing-masing ditambahkan $3,5 \mathrm{~mL}$ 
Potensi senyawa flavonoid daun afrika (Vernonia amygdalina Del.) asal Ternate sebagai antioksidan

DPPH. Kemudian divortex dan di inkubasi selama 30 menit pada suhu $37^{\circ} \mathrm{C}$. Kemudian diukur serapannya. Serapannya diukur pada panjang gelombang $515 \mathrm{~nm}^{7}$

\section{Pengukuran Aktivitas Antioksidan}

Ekstrak Daun Afrika (Vernonia amygdalina Del.)

Dibuat larutan stok 1000 ppm. Selanjutnya dilakukan pengenceran dengan seri konsentrasi 20 ppm, 40 ppm, 60 ppm, 80 ppm, 100 ppm, kemudian dicukupkan volumenya hingga $5 \mathrm{~mL}$.

Persentase persentasi radikal bebas di hitung dengan persaman ${ }^{8}$ $\%$ Inhibisi $=\frac{\text { Abs Blangko-Abs Sampel }}{\text { Abs Blangko }} \times 100 \%$ Dari persamaan $\mathrm{y}=\mathrm{a}+\mathrm{bx}$ dapat dihitung nilai $\mathrm{IC}_{50}$

\section{Perhitungan nilai} AAI (Antioxidant Activity Index) digunakan untuk mengetahui index aktivitas antioksidan dengan rumus:

Nilai AAI $=\frac{\text { Konsentrasi } D P P H(p p m)}{I C 50 \text { Sampel }(p p m)}$

Uji aktivitas Antioksidan Metode FRAP

Pengujian dilakukan berdasarkan metode penilitian yang dilakukan oleh Maryam, Muzakkir, \&
Ainun (2015) dengan sedikit modifikasi. $^{9}$

Pengukuran Aktivitas Antioksidan Ekstrak Daun Afrika (Vernonia amygdalina Del.)

Ekstrak etanol daun afrika ditimbang sebanyak $10 \mathrm{mg}$ dilarutkan dalam $10 \mathrm{~mL}$ etanol 96\% (1000 ppm) dilakukan sebanyak tiga kali replikasi. Larutan stok dipipet sebanyak $1 \mathrm{~mL}$ dan dicukupkan volumenya sampai 10 $\mathrm{mL}$ dengan etanol $96 \%$ sehingga diperoleh konsentrasi 100 ppm. Larutan ekstrak dengan konsentrasi 100 ppm dipipet $1 \mathrm{~mL}$ ditambahkan dapar fosfat $(\mathrm{pH}$ 6.6) $1 \mathrm{~mL}$ dan $\mathrm{K}_{3} \mathrm{Fe}(\mathrm{CN})_{6}$ sebanyak $1 \mathrm{~mL}$. Setelah itu, diinkubasi selama 20 menit dengan suhu $50^{\circ} \mathrm{C}$. Setelah diinkubasi ditambahkan TCA $1 \mathrm{~mL}$ lalu disentrifuge 3000 rpm 10 menit. Setelah disentifuge lapisan atas dari campuran larutan dipipet $1 \mathrm{~mL}$ kedalam tabung reaksi, dan ditambahkan aquades $1 \mathrm{~mL}$ dan $\mathrm{FeCl}_{3}$ $0,05 \%$ sebanyak $0,5 \mathrm{~mL}$. Larutan didiamkan selama 10 menit dan dilakukan pengukuran serapan pada panjang gelombang $720 \mathrm{~nm}$. 
Potensi senyawa flavonoid daun afrika (Vernonia amygdalina Del.) asal Ternate sebagai antioksidan

\section{HASIL PENELITIAN}

Tabel 1. Persen rendamen ekstrak daun Afrika

\begin{tabular}{cccc}
\hline Sampel & Berat awal $\mathbf{( g )}$ & Hasil Ekstrak (g) & Rendamen (\%) \\
\hline Daun Afrika & 100 & 20,015 & 4,003 \\
\hline
\end{tabular}

Tabel 2. Hasil Identifikasi Flavanoid

\begin{tabular}{ccc}
\hline Uji & Reagen & Hasil \\
\hline Flavonoid & $\mathrm{Mg}+2 \mathrm{~mL} \mathrm{HCl} 2 \mathrm{~N}$ & + \\
\hline
\end{tabular}

Tabel 3. Hasil pengukuran absorbansi, persentasi inhibisi, nilai $\mathrm{IC}_{50}$, nilai $\mathrm{AAI}$ ekstrak daun Afrika (Vernonia amygdalina Del.) dan pembanding kuersetin

\begin{tabular}{cccccc}
\hline Sampel & Konsentrasi (ppm) & Abs & \%inhibisi & IC $_{50}(\mathbf{p p m})$ & AAI \\
\hline Blanko & 40 & 0,639 & - & - & - \\
& 20 & 0,562 & 12,050 & & \\
Ekstrak etanol & 40 & 0,503 & 21,282 & & \\
daun afrika & 60 & 0,416 & 34,898 & 87,992 & 0,454 \\
& 80 & 0,344 & 46,165 & & \\
& 100 & 0,279 & 56,388 & & \\
Kuersetin & 2 & 0,479 & 25,039 & & \\
& 4 & 0,398 & 37,715 & & 6,315 \\
& 6 & 0,322 & 49,608 & 6,334 & \\
\hline
\end{tabular}

Tabel 4. Hasil pengukuran serapan larutan pembanding kuersetin dengan spektrofotometer pada panjang $720 \mathrm{~nm}$.

\begin{tabular}{cc}
\hline Konsentrasi (ppm) & Absorban \\
\hline 2 & 0,280 \\
4 & 0,335 \\
6 & 0,385 \\
8 & 0,441 \\
10 & 0,512 \\
\hline
\end{tabular}

Tabel 5. Hasil Pengukuran Uji Aktivitas Ekstrak Etanol Daun Afrika pada dengan spektrofotometer UV-Vis

\begin{tabular}{cccc}
\hline $\begin{array}{c}\text { Ekstrak } \\
\text { Etanol Daun Afrika }\end{array}$ & $\begin{array}{c}\text { Abs } \\
(\mathbf{7 2 0} \mathbf{~ n m})\end{array}$ & $\begin{array}{c}\text { Kadar } \\
(\mu \mathrm{g} / \mathrm{mgQE})\end{array}$ & $\begin{array}{c}\text { Kadar } \\
\text { rata }- \text { rata } \\
(\boldsymbol{\mu g} / \mathrm{mgQE})\end{array}$ \\
\hline $\mathrm{R} 1$ & 0,252 & 11,756 & \\
$\mathrm{R} 2$ & 0,261 & 14,970 & $14,846 \mathrm{mgQE} / \mathrm{gram}$ \\
$\mathrm{R} 3$ & 0,269 & 17,814 & \\
\hline
\end{tabular}


Potensi senyawa flavonoid daun afrika (Vernonia amygdalina Del.) asal Ternate sebagai antioksidan

\section{PEMBAHASAN}

Pada penelitian yang dilakukan Metode ekstraksi yang digunakan adalah metode maserasi yang merupakan metode ekstraksi dingin. Metode maserasi dipilih karena dapat menarik komponen kimia yang terdapat dalam sampel tanpa merusak senyawanya. Proses maserasi dilakukan dengan menggunakan pelarut etanol $96 \%$ yang memiliki tingkat kepolaran yang tinggi. Setelah proses ektraksi ekstrak cair dikumpulkan kemudian diuapkan menggunakan alat komponen kimia yang terdapat dalam sampel tanpa merusak senyawanya. Proses maserasi dilakukan dengan menggunakan pelarut etanol 96\% yang memiliki tingkat kepolaran yang tinggi. Setelah proses ektraksi ekstrak cair dikumpulkan kemudian diuapkan menggunakan alat rotavapor (rotary vacum evaporator) dengan tujuan untuk mendapatkan ekstrak etanol kental. Ekstrak yang diperoleh untuk daun sebanyak 20,015 gram.

Hasil positif pada uji flavonoid dimana logam $\mathrm{Mg}$ dan $\mathrm{HCl}$ pada uji ini berfungsi untuk mereduksi inti benzopiron yang terdapat pada struktur flavonoid sehingga terbentuk perubahan warna menjadi merah atau jingga.
Hasil pengukuran larutan standar kuersetin yang kemudian dibuat kurva baku antara konsentrasi dengan persen penghambatan DPPH diperoleh dengan nilai $y=5,485 x+$ 15,258 nilai $r^{2}=0,995$ dan nilai $r=$ 0,997 dapat dilihat pada lampiran 4 . Sedangkan untuk sampel ekstrak daun afrika diperoleh dengan nilai $\mathrm{y}=$ $0,567 x+0,108 \cdot R^{2}=0.997$ dan nilai $r$ $=0,998$. Memenuhi syarat linearitas yaitu nilai $r>0,995$. Sehingga dari nilai yang diperoleh terdapat hubungan korelasi antara persen penghambatan DPPH dan konsentrasi sampel.

Suatu senyawa dinyatakan sebagai antiradikal bebas sangat kuat apabila nilai $\mathrm{IC}_{50}<10$ ppm, kuat apabila nilai $\mathrm{IC}_{50}$ antara 10-50 ppm, sedang apabila nilai $I_{50}$ berkisar antara 50-100 ppm, lemah apabila nilai $\mathrm{IC}_{50}$ berkisar antara 100-250 ppm dan tidak aktif apabila $I_{50}$ diatas 250 ppm. $^{8}$

Pada metode FRAP merujuk pada prosedur (Maryam, Muzakkir, \& Ainun (2015) dengan sedikit modifikasi. $^{9} \quad$ Panjang gelombang maksimum $720 \mathrm{~nm}$. Dimana pengukuran absorbansi pembanding kuersetin dengan konsentrasi 2, 4, 6, 8, dan 10 ppm sedangkan konsentrasi sampel 100 ppm di buat dalam tiga replikasi. 
Potensi senyawa flavonoid daun afrika (Vernonia amygdalina Del.) asal Ternate sebagai antioksidan

\section{KESIMPULAN}

Senyawa flavonoid daun Afrika (Vernonia amygdalina Del.) berpotensi sebagai antioksidan. Pada metode DPPH ekstrak etanol daun afrika (Vernonia amygdalina Del.) memiliki nilai $\mathrm{IC}_{50}$ yaitu $87,992 \mathrm{ppm}$ dan aktivitas antioksidan lemah berdasarkan nilai AAI 0,454 sedangkan kapasitas antioksidan pada metode FRAP yaitu 14,846 $\mathrm{mgQE} /$ gram yang artinya dalam setiap gram sampel setara dengan 14,846 mg kuersetin sebagai antioksidan.

\section{DAFTAR PUSTAKA}

1. Audu SA, Taiwo AE, Sani, SA, Sani AS, Bukola AR, Mohammed, I. A Study Review of Documented Phytochemistry of Vernonia amygdalina (Family Asteraceae) as the Basis for Pharmacologic Activity of Plant Extract. Journal of Natural Sciences Research 2012;2(7):6.

2. Kharimah, ZN, Lukmayani $Y$, Syafnir L. Identifikasi Senyawa Flavonoid pada Ekstrak dan Fraksi Daun Afrika (Vernonia amygdalina Del.)', Journal 2016; 2: 708.

3. ljeh I, Ifeoma, Ejike CE Chukwunonso. Current Perspectives On The Medicinal Potentials Of Vernonia amygdalina
Del', Journal Medicinal Plants Research 2010;(7): 1052-1055.

4. Winarsih H. Antioksidan Alami dan Radikal Bebas ; Potensi dan Aplikasinya dalam Kesehatan, Yogyakarta : Kanisius; 2007

5. Koireoa YA, Fatimawali, Wiyono WI. 'Isolasi dan Identifikasi Senyawa Flavonoid dalam Daun Beluntas (Pluchea indica L.). Manado : Program Studi Farmasi, FMIPA UNSRAT; 2012.

6. Hassan MN. 2014. Uji Kandungan Flavonoid dan Perbandingan Aktivitas Antioksidan Pada Ekstrak Etanol Simplisia Bunga Pepaya Gantung Saat Kuncup dan Mekar.

7. Maryam S, Baits $M$, Nadia, $A$, Pengukuran Aktivitas Antioksidan Ekstrak Etanol Daun Kelor (Moringa oleifera Lam.) Menggunakan Metode FRAP (Ferric Reducing Antioxidant Power), Jurnal Fitofarmaka Indonesia 2015; 2(2) : 115-118.

8. Zuhra Cut Fatimah, Tarigan, Juliati BR, Sihotang Herlince. Aktivitas Antioksidan Senyawa Flavonoid Dari Daun Katuk (Sauropus androgunus (L) Merr.) 2008;3(1):9

9. Pongpaichit S, Nikom J, Rungjindamai N, Sakayaroj J, Hutadilok-Towatana N, Rukachaisirikul V, Kirtikara K. Biological Activities of Extracts From Endophytic Fungi Isolated From Garcinia Plants. Immunology \& Medical Microbiology 2007:5152. 